\title{
The occurrence of Enterobacteriaceae bacteria in feathers after slaughter of poultry
}

\author{
Krystyna Cybulska, Sanaa Mahdi Oraibi, Barbara Jakubowska
}

Department of Chemistry, Microbiology and Environmental Biotechnology, West Pomeranian University in Szczecin, Słowackiego 17 St, 71-434 Szczecin, Poland, email: krystyna.cybulska@zut.edu.pl

Received: 27 September 2017/ Accepted: 16 November 2017

\begin{abstract}
The Enterobacteriaceae family is a very diverse group of microorganisms. Especially, it contains in its composition a unit of a pathogenic nature causing serious illnesses and health problems of people and animals. They are a huge problem in the environment of animal husbandry, processing and waste management.

The purpose of this work was to determine the amount of contaminants with Enterobacteriaceae bacteria species after the slaughter of different poultry species. The study used a pre-selective propagation technique on MacConkey's liquid medium. To confirm the presence of Enterobacteriaceae bacteria, the inoculation onto VRBDA medium was made. The numbers of population and results of the tests allowed for calculating the MPN and the titre of tested bacteria group. Tested samples contained feather waste after slaughter of poultry, i.e. chickens, ducks, geese and turkeys. Material was collected at different dates from three poultry slaughterhouses in Western Poland.

Based on the results obtained, the numerous presence of Enterobacteriaceae family bacteria has been confirmed in the waste feathers of various poultry species following the slaughter. The number of Enterobacteriaceae bacteria differed significantly in different materials and dates of measurement, which could be due to the heterogeneity of the animals supplied to the plants.
\end{abstract}

Key words: Enterobacteriaceae, waste poultry, feathers.

\section{Introduction}

Enterobacteriaeceae and Escherichia coli are more frequently used to assess enteric contamination (Ghafir et al., 2008). Enterobacteriaceae are defined as Gram-negative, glucose fermenting, oxidase negative, usually catalase-positive and nitrate reducing organisms. This family includes many bacteria associated with faeces, but also many nonfaecal organisms (Schaffner \& Smith, 2004). Salmonella, Proteus, Escherichia coli, Klebsiella, Shigella, Morganella, Enterobacter, Citrobacter, and Serratia belonging to Enterobacteriaceae family (Farmer, 2003; Abbott, 2007). The proliferation of Enterobacteriaceae on poultry carcasses has been routinely linked to inadequate or unhygienic processing or inappropriate handling or storage conditions
(Whyte et al., 2003). The family Enterobacteriaceae, including Escherichia coli, Salmonella spp. and Klebsiella spp. are a major or secondary pathogens poultry production (Kilonzo-Nthenge et al., 2008; Obi et al., 2009). Enterobacteriaceae family is divided into three groups on the basis of lactose fermenter as follows: I-lactose fermenters, such as Escherichia coli, Enterobacter spp., and Klebsiella spp.; II-late lactose fermenters, such as Citrobacter spp. and Serratia spp. and III-lactose nonfermenter, such as Edwardsiella tarda, Hafnia, Morganella morganii, Proteus spp., Providencia spp., Salmonella spp., Shigella spp., and Yersinia spp. (Forbes et al., 2007; Khan et al., 2011). Enterobacteriaceae are distributed widely in nature and in the gastrointestinal tract of humans, other mammals, and birds. Previous studies (Barham et al., 2002; Fluckey et al., 
2007; Mainali et al., 2009). They are found in soil, water, fruits, meats, eggs, vegetables, grains, flowering plants and trees, and in animals from insects to human (Brenner et al., 2005). Total Enterobacteriaceae count and total coliforms count are more frequently used to assess enteric contamination and commonly used in slaughterhouses as indicators of faecal as well as environmental contamination (Gonzalez-Fandos \& Dominguez, 2006).

Feathers are generated in large quantities as a by-product of poultry industry (Zaghloul et al., 2011; Azeredo et al., 2006). Chicken feather is organic waste that accumulated in bulk quantities as a by-product in poultry industry. In general, each bird has up to 125 gram of feather (Lakshmi et al., 2013) that represent 5-7\% of the total weight of mature chickens (Matikevičienë et al., 2009). Meanwhile, more than 400 million chickens being processed every week worldwide (Lakshmi et al., 2013) hence the accumulation of feather waste reaches five million tons (Han et al., 2012; Daroit et al., 2011; Zerdani et al., 2004; Suneetha \& Lakshmi, 2004). Most feather waste is land filled or burned that cause global environmental issue such as pollution of both air and underground water resources (Cai et al., 2008; Matikevičienë et al., 2009) and protein discharge (Cai et al., 2008).

The purpose of this work was to determine the amount of contaminants with Enterobacteriaceae bacteria species in waste after the slaughter of different poultry species.

\section{Material and methods}

The study included 16 feather samples (chicken -8 , duck -4 , turkey -3 , goose -1 ) collected in 3 slaughterhouses marked with symbols 1(B), 2(P), and 3(D) in the West Pomeranian and Lubuskie provinces in Poland from January 2015 to April 2016. Due to the fact that these are the largescale industrial conditions, the sampling was possible depending on the supplies and conditions prevailing at a given facility. Hence, the variability and heterogeneity of analyzed samples should be taken into account. It should be emphasized, however, that this will allow to demonstrate the scale of waste pollution in the form of various feathers after the slaughter of animals, which will be managed in a different way at a later stage. Such materials are usually contacted by service personnel, and they can be found in the environment to a greater or lesser degree, and can be dangerous to humans and animals.

In a study to evaluate the prevalence and abundance of Enterobacteriaceae, the pre-selective propagation on MacConkey Broth procedure was used. From subsequent decimal dilutions $\left(10^{-1}-10^{-9}\right), 1 \mathrm{ml}$ samples were inoculated into three parallel tubes with MacConkey medium and Durham tubes. Incubation was carried out at $37^{\circ} \mathrm{C}$ for 24-48 hours. To confirm the presence of Enterobacte- riaceae from the test tubes with positive result, i.e. color change to yellow and gas presence for 3 consecutive dilutions, a reduction inoculation was applied to the solidified VRBDA medium (Violet Red Bile Dextrose Agar). The dishes were incubated at $35^{\circ} \mathrm{C}$ and after 24 hours, readings were made on the basis of characteristic appearance of colonies. Positive results obtained on VRBDA substrate were used to calculate the most probable number (MPN) and the titre of tested bacteria group in $1 \mathrm{~g}$ of dry matter (European Pharmacopeia, 2011; Mossel, 1985; USP 33 NF 28, 2011).

\section{Results nad discussion}

Based on achieved results, quite numerous presence of Enterobacteriaceae family bacteria was found in feathers after animal slaughter amounting from over $10^{5}$ to almost $10^{12}$ MPN $\cdot 1 \mathrm{~g}^{-1} \mathrm{DM}$. Differences in population number of these bacteria in particular samples appeared to be highly significant. Total Enterobacteriaceae count and total coliforms count are more used in slaughterhouses as indicators of faecal as well as environmental contamination (Gonzalez-Fandos \& Dominguez, 2006).

Infection of chicken feathers with Enterobacteriaceae species ranged from about $10^{6}$ to nearly $10^{12} \mathrm{MPN} \cdot 1 \mathrm{~g}^{-1}$ DM. It was significantly larger in the first half of 2015, then it was still two orders of magnitude lower. A similar tendency was also noted for duck feathers. The results for turkey feathers were much more uniform. The average values for different types of feathers indicate that the greatest infection occurred for duck feathers and then in descending order for chicken, turkey and goose feathers (respectively: $3 \cdot 10^{11} \mathrm{MPN} \cdot 1 \mathrm{~g}^{-1} \mathrm{DM}, 6 \cdot 10^{10} \mathrm{MPN} \cdot 1 \mathrm{~g}^{-1} \mathrm{DM}$, $\left.1 \cdot 10^{10} \mathrm{MPN} \cdot 1 \mathrm{~g}^{-1} \mathrm{DM}, 5 \cdot 10^{7} \mathrm{MPN} \cdot 1 \mathrm{~g}^{-1} \mathrm{DM}\right)$. The differences reached up to 4 orders of magnitude (Fig. 1). Scattering of results obtained for these types of feathers was also reduced in the same order: largest for duck feathers with a gradual decrease for chicken, turkeys and goose.

At the slaughterhouse No. 1 (B), the contamination of feathers with Enterobacteriaceae species bacteria was the highest in April-May ( $\left.10^{11} \mathrm{MPN} \cdot 1 \mathrm{~g}^{-1} \mathrm{DM}\right)$. Other results for this location were lower by 3-4 orders of magnitude. At the slaughterhouse No. 3 (D), the amount of contamination was constant, and only in the first two days there was a greater number of bacteria. A similar level of bacterial infection occurred for location $2(\mathrm{P})$ at both study dates. Average results obtained for each site indicate the largest infection with Enterobacteriaceae in location No 1 (B), by approximately one order of magnitude smaller in location 3 (D) and by another 3 orders of magnitude in location No 2(P), respectively: $1 \cdot 10^{11} \mathrm{MPN} \cdot 1 \mathrm{~g}^{-1} \mathrm{DM}, 1 \cdot 10^{10}$ MPN $\cdot 1 \mathrm{~g}^{-1} \mathrm{DM}, 1 \cdot 10^{7} \mathrm{MPN} \cdot 1 \mathrm{~g}^{-1} \mathrm{DM}$. At location No. 1(B), the greatest number of scattered records was observed, sig- 
nificantly smaller in locations No. 3(D) and 2(P) (Fig. 2). It seems that the reason for such a differentiation of the slaughterhouse is that in the last two species only two bird species were processed [3(D) - chickens, 2(P) - turkeys], whereas there are four species in slaughterhouse No. 1(B).

Considering the average size of feather infection with Enterobacteriaceae bacteria on individual dates, it is possible to find their larger numbers in April-May 2015 and to a lesser extent also in January and November 2015 (Fig. 3). In other terms, this figure is at a lower level, within limits of $10^{6}-10^{8} \mathrm{MPN} \cdot 1 \mathrm{~g}^{-1} \mathrm{DM}$.

The cluster analysis indicates a significant uniformity of the obtained results. Only the goose feather sample from slaughterhouse No. 1(B) in May 2015 and to a smaller extent, goose and chicken feathers from the same location in April 2015 are different in nature (Fig. 4). The proliferation of Enterobacteriaceae on poultry carcasses or waste has been routinely linked to inadequate or unhygienic processing or inappropriate handling or storage conditions (Whyte et al., 2003). Feathers are generated in large quantities as a by-product of poultry industry (Zaghloul et al., 2011; Azeredo et al., 2006). Most feather waste is land filled or burned that cause global environmental issue such as pollution of both air and underground water resources (Cai et al., 2008; Matikevičienë et al., 2009) and protein discharge (Cai et al., 2008).

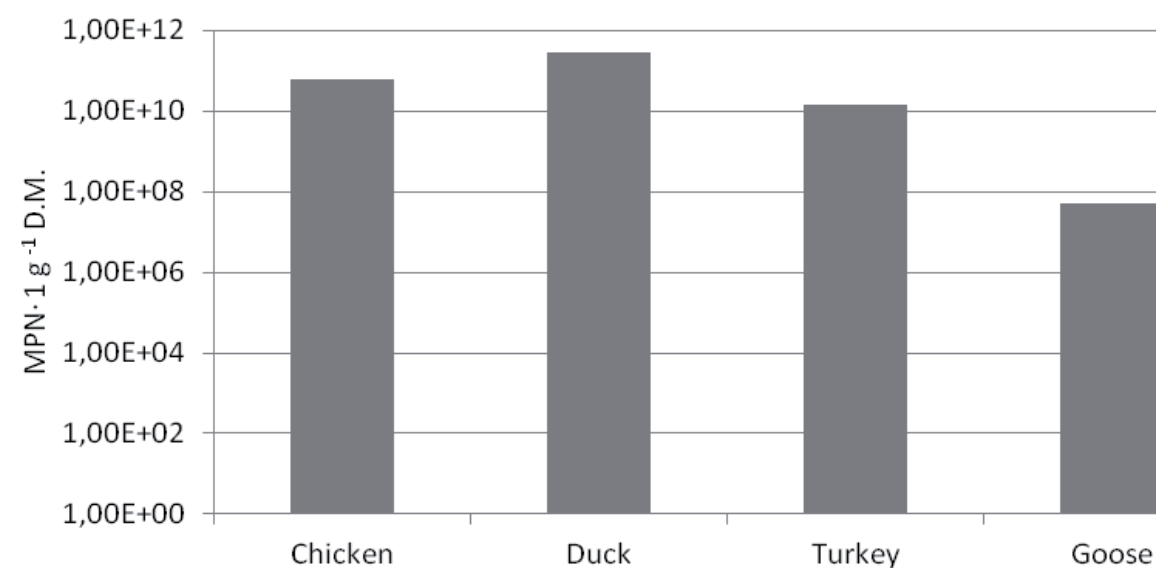

Figure 1. Average number of Enterobacteriaceae species bacteria for different types of feathers

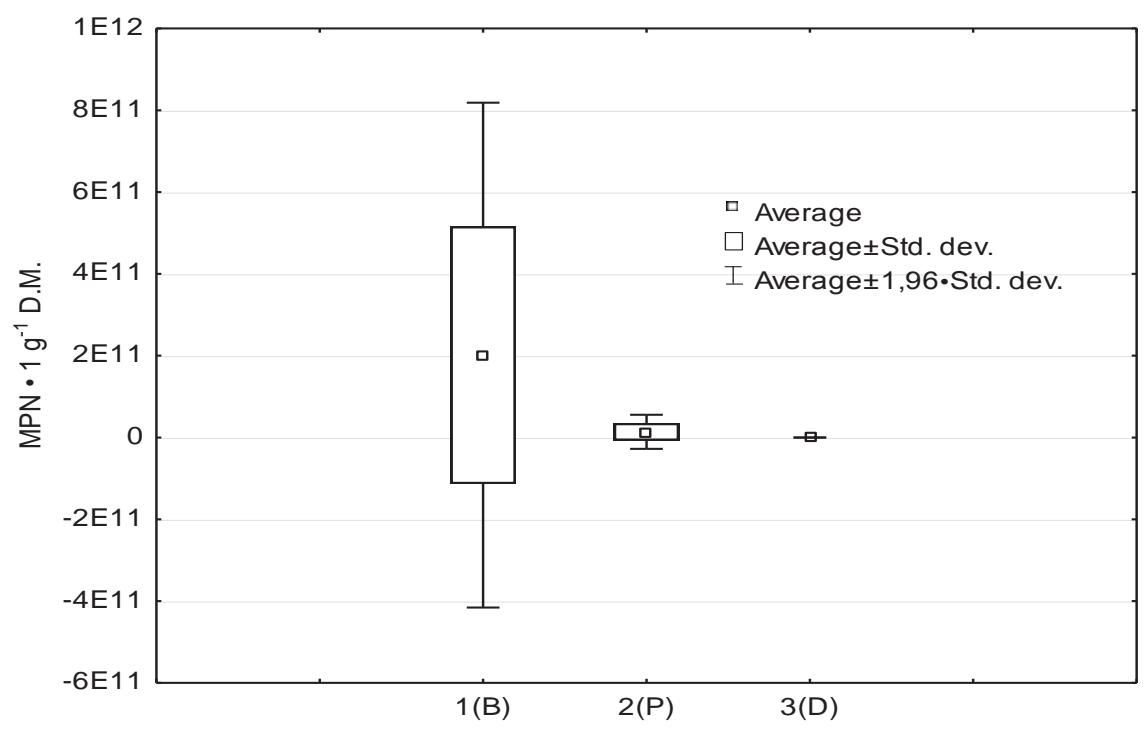

Figure 2. Spread of results of Enterobacteriaceae population in different locations 


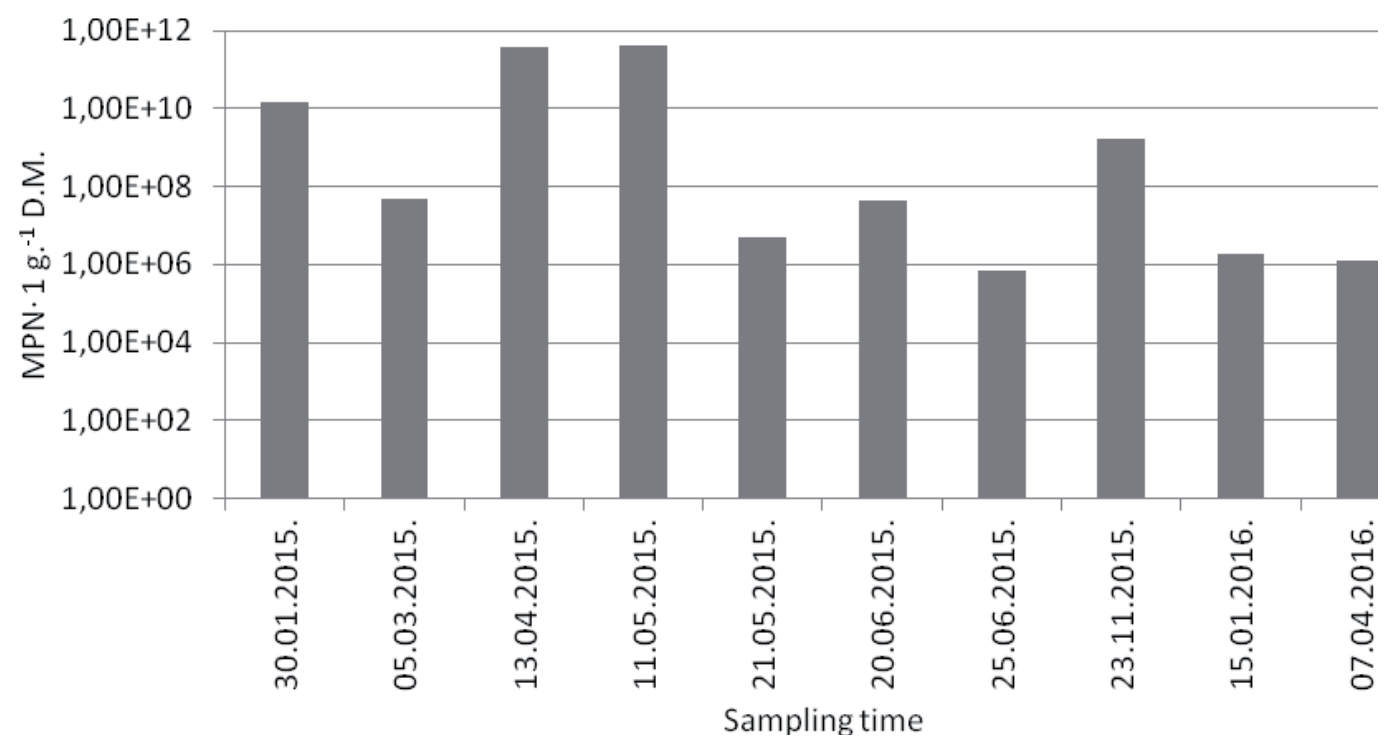

Figure 3. The average number of Enterobacteriaceae bacteria in particular terms

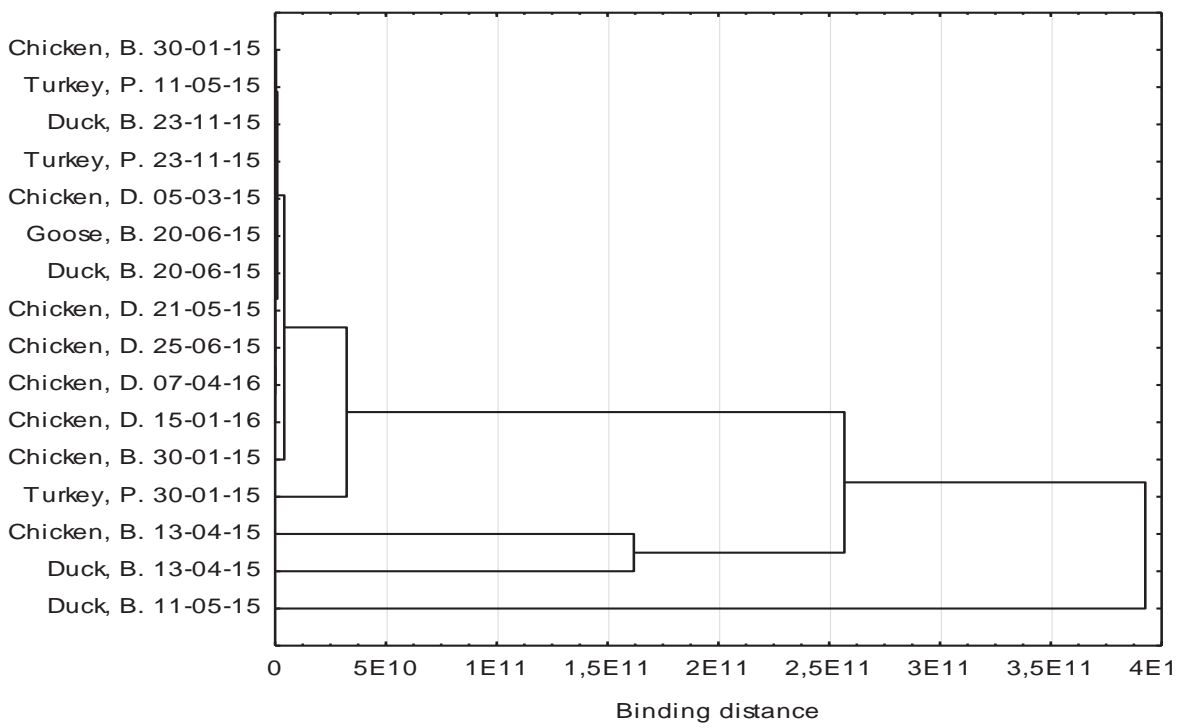

Figure 3. Cluster analyzes for the results of Enterobacteriaceae bacteria population in feathers after the slaughter of different poultry species

\section{Conclusions}

1. Based on the obtained results, it was found that contamination of feathers after poultry slaughter with Enterobacteriaceae is significant and within the limits of $10^{5}$ $-10^{12} \mathrm{MPN} \cdot 1 \mathrm{~g}^{-1} \mathrm{DM}$.

2. During the study period, the highest infection with Enterobacteriaceae bacteria occurred in April-May and partly in January-November. Due to the type of feathers tested, they can be ranked (in decreasing order of infection) as follows: duck, chicken, turkey, goose.

3. The amount of feathers contaminated with Enterobacteriaceae family bacteria may be related to the quality of the material delivered to the slaughterhouse as well as hygiene rules and technological standards. Consequently, significant differences in bacterial populations were found in the slaughterhouse 1(B) and then in descending order in 3(D) and 2(P) slaughterhouses. 


\section{References}

Abbott S.L., 2007, Klebsiella, Enterobacter, Citrobacter, Serratia, Plesiomonas, and other Enterobacteriaceae, [in:] Manual of clinical microbiology. 9th edition, Murray PR, E,J. Baron, J.H. Jorgensen, M.L. Landry, M.A. Pfaller (eds). American Society for Microbiology Press, Washington, DC: 698-715.

Azeredo L., Lima M., Coelho R. \& Freire D., 2006, Thermophilic protease production by Streptomyces sp. 594 in submerged and solid-state fermentations using feather meal. Journal of Appllied Microbiology 100: 641-647.

Barham A.R., Barham B.L., Johnson A.K., Allen D.M., Blanton J.R. \& Miller F.M., 2002, Effects of the transportation of beef cattle from the feed yard to the packaging plant on prevalence levels of Escherichia coli O157 and Salmonella spp. Journal of Food Protection 65: 280-283.

Brenner D.J., Krieg N.R., Staley J.T., Garrity G.M., Boone D.R., De Vos P., Goodefellow M., Rainey F.A. \& Schleifer K.H., 2005, Bergey's. Manual of Systematic Bacteriology, 2nd Edition. Michigan State University, Springer, East Lansing.

Cai C.G., Lou B.G. \& Zheng X.D., 2008, Keratinase production and keratin degradation by a mutant strain of Bacillus subtilis. Journal of Zhejiang UniversityScience B 9(1):60-67. [DOI:10.1631/jzus.B061620].

Daroit D.J., Corręa A.P.F. \& Brandelli A., 2011, Production of keratinolytic proteases through bioconversion of feather meal by the Amazonian bacterium Bacillus sp. P45. International Biodeterioration \& Biodegradation, 65: 45-51.

European Pharmacopoeia 7.0, 2011, 7th ed. § 2.6.13. Microbiological examination of non-sterile products: Test for specified microorganisms, Harmonised Method. EDQM. Council of Europe, Strasbourg.

Farmer J.J., III, 2003, Enterobacteriaceae: introduction and identification, [in:] P. Murray, E.J. Baron, J.H. Jorgensen, R.H. Yolken, MA. Pfaller (eds), Manual of clinical microbiology. American Society for Microbiology Press, Washington DC: 636-653.

Fluckey W.M., Loneragan G.H., Warner R. \& Brashears M.M., 2007, Antimicrobial drug resistance of Salmonella and Escherichia coli isolates from cattle feces, hides, and carcasses. Journal of Food Protection 70: 551-556.

Forbes B.A., Sahm D.F. \& Weissfeld A.S., 2007, Bailey \& Scott's Diagnostic Microbiology, 12th Edition. Elsevier Mosby, St. Louis.

Ghafir Y., China B., Dierick K., De Zutter, Daube G., 2008, Hygiene indicator microorganisms for selected patho- gens on beef, pork, and poultry meats in Belgium. Journal of Food Protection 71: 35-45.

Gonzalez-Fandos E. \& Dominguez J.L., 2006, Efficacy of lactic acid against Listeria monocytogenes attached to poultry skin during refrigerated storage. Journal Applied Microbiology 101: 1331-1339. [DOI: 10.1111/j.1365-2672.2006.03022.x].

Han M., Luo W., Gu. Q. \& Yu X., 2012, Isolation and Characterization Of A Keratinolytic Protease From A Feather-Degrading Bacterium Pseudomonas aeruginosa C11. African Journal of Microbiology Research 6: 2211-2221. [DOI: 10.5897/AJMR11.921].

Khan F.R.M., Rizvi M., Shukla I. \& Malik A., 2011, A Novel Approach for Identification of Members of Enterobacteriaceae Isolated from Clinical Samples. Biology and Medicine 3: 313-319.

Kilonzo-Nthenge A., Nahoshon S.N., Chen F. \& Adefope N., 2008, Prevalence and antimicrobial resistance of pathogenic bacteria in chicken and guinea fowl. Poultry Science 87: 1841-1848. (https://doi. org/10.3382/ps.2007-00156).

Lakshmi P.J., Chitturi Ch.M.K. \& Lakshmi V.V., 2013, Efficient Degradation of Feather by Keratinase Producing Bacillus sp. International Journal of Microbiology Vol. 2013, Article ID 608321 1-7. (http://dx.doi. org/10.1155/2013/608321).

Mainali C., Gensler G., McFall M., King R., Irwin R. \& Senthilselvan A., 2009, Evaluation of association between feed withdrawal and other management factors with Salmonella contamination of broiler chickens at slaughter in Alberta. Journal of Food Protection 72: 2202-2207.

Matikevičienė V., Masiliūnienė D. \& Grigiškis S., 2009, Degradation of Keratin Containing Wastes by Bacteria with Keratinolytic Activity. Proceedings of the 7th International Scientific and Practical Conference. Rēzeknes Augstskola, Rēzekne, RA Izdevniecība.

Mossel D.A.A., 1985, Media for Enterobacteriaceae. International Journal of Food Microbiology 2: 27-35.

Obi T.U., Olubukola A. \& Maina G.A., 2009, Pro-Poor HPAI Risk Reduction Strategies in Nigeria-Background Paper. International Food Policy Research Institute (IFPRI), Africa/Indonesia, Team Working Paper No. 5.

Schaffner D.W. \& Smith S., 2004, Indicator organisms, [in:] Encyclopaedia of Meat Sciences. Elsevier, Academic Press, Amsterdam: 773-773.

Suneetha V. \& Lakshmi V.V., 2004, Fermentaitve production of kerazyme with isolates from Tirumall Hills, [in:] A.M. Deshmukh (ed.), Biotechnology in agriculture industry and environment. Microbiology Society, Karad, India: 198-203.

USP 33 - NF 28, 2011, Microbiological examination of non-sterile products: Test for specified microorgan- 
isms. Harmonised Method. USP Corp. Inc., Rockville, MD, USA.

Whyte P., McGill K. \& Collins J., 2003, An assessment of steam pasteurization and hot water immersion treatments for the microbiological decontamination of broiler carcasses. Food Microbiology 20(1): 111-117.

Zaghloul T.I., Embaby A.M. \& Elmahdy H., 2011, Key determinants affecting sheep wool biodegradation direc- ted by a keratinase producing Bacillus subtilis recombinant strain. Biodegradation 10: 9381-9389. [DOI: 10.1007/s10532-010-9381-9].

Zerdani I., Faid M. \& Malki A., 2004, Feather wastes digestion by new isolated strains Bacillus sp. in Morocco. African Journal of Biotechnology 3: 67-70. [DOI: 10.5897/AJB2004.000-2012]. 